\title{
Short Report on an Intensive Archeological Survey for the City Of Lockhart's Proposed Sidewalk Improvements Project, Lockhart, Caldwell County, Texas
}

Josh Haefner

Steven Sarich

Follow this and additional works at: https://scholarworks.sfasu.edu/ita

Part of the American Material Culture Commons, Archaeological Anthropology Commons, Environmental Studies Commons, Other American Studies Commons, Other Arts and Humanities Commons, Other History of Art, Architecture, and Archaeology Commons, and the United States History Commons

Tell us how this article helped you.

This Article is brought to you for free and open access by the Center for Regional Heritage Research at SFA ScholarWorks. It has been accepted for inclusion in Index of Texas Archaeology: Open Access Gray Literature from the Lone Star State by an authorized editor of SFA ScholarWorks. For more information, please contact cdsscholarworks@sfasu.edu. 


\section{Short Report on an Intensive Archeological Survey for the City Of Lockhart's Proposed Sidewalk Improvements Project, Lockhart, Caldwell County, Texas}

\section{Creative Commons License}

\section{(c) (1) (8)}

This work is licensed under a Creative Commons Attribution-NonCommercial 4.0 International License 


\title{
SHORT REPORT ON AN INTENSIVE ARCHEOLOGICAL SURVEY FOR THE CITY OF LOCKHART'S PROPOSED SIDEWALK IMPROVEMENTS PROJECT, LOCKHART, CALDWELL COUNTY, TEXAS
}

\author{
By: \\ Josh Haefner and Steven Sarich
}

Prepared for:

City of Lockhart

Prepared by:

TRC Environmental Corporation

Austin, Texas

Texas Antiquities Permit No. 9126

Josh Haefner, Principal Investigator

TRC Technical Report No. 352404.1000

November 2019 
This page intentionally left blank 


\section{TABLE OF CONTENTS}

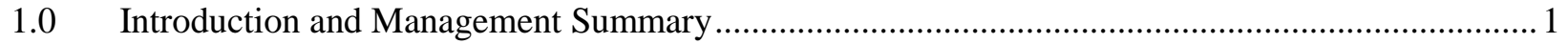

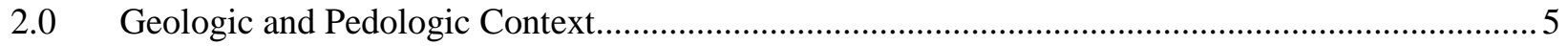

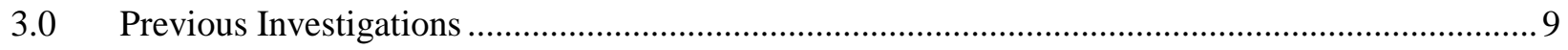

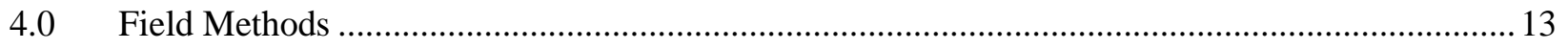

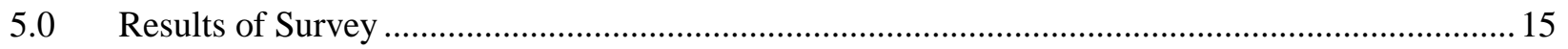

6.0 Project Summary and Recommendations .................................................................................. 23

\section{LIST OF FIGURES}

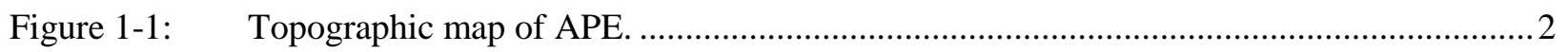

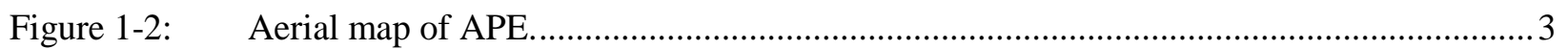

Figure 2-1: $\quad$ Underlying geology within and adjacent to the APE.................................................... 6

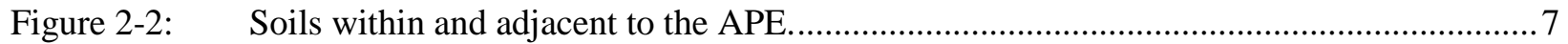

Figure 3-1: $\quad$ Previously recorded cultural resources within a $1 \mathrm{mi}$ - of the APE. ................................. 10

Figure 4-1: $\quad$ Overview of systematic mechanical scraping in progress, facing north......................... 14

Figure 5-1: $\quad$ Shovel Test and mechanical scraping locations............................................................. 16

Figure 5-2 Overview of APE, facing west with centerline of 10' wide trail located south of fence line and nearest row of graves upslope to the north............................................................ 17

Figure 5-3: Overview of APE, facing northeast showing pond and location of No Dig shovel test ST-

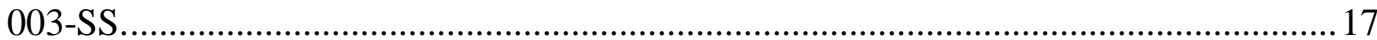

Figure 5-4: Overview of APE, facing east showing the survey end point and ground disturbance....18

Figure 5-5 Overview of cemetery; the APE is on the other side of the fence, facing east................ 18

Figure 5-6: Cut stone fragments found downslope from the cemetery along the fence line............... 19

Figure 5-7: Cut stone fragments found downslope from the cemetery along the fence line............... 19

Figure 5-8: Close up of mechanical scraping area in planview.........................................................2 21

Figure 5-9: Overview of mechanical scraping facing west showing westward sloping landscape.....22

Figure 5-10: Cemetery scraping soil profile facing north..............................................................22

Figure 5-11: Cemetery scraping overview facing northeast terminated at dense layer of cobbles. ......22 


\section{LIST OF TABLES}

Table 3-1: $\quad$ Previously Recorded Cultural Resources within a 1 mile of the APE. ............................. 11

Table 3-2: $\quad$ Previously conducted archeological surveys within a 1 mile of the APE...........................12

Table 3-3: $\quad$ Historical Markers within a 1 mile of the APE. ................................................................12

\section{LIST OF APPENDICES}

Appendix A Design Plans

Appendix B Regulatory Correspondence 


\subsection{INTRODUCTION AND MANAGEMENT SUMMARY}

On behalf of the City of Lockhart (the City), TRC Environmental Corporation (TRC) recently conducted an intensive archeological survey for the City's sidewalk improvements project located in Lockhart, Caldwell County, Texas. According to design plans, the project will entail the construction of a 10-foot (ft) wide by 2,220 ft long concrete sidewalk that will enhance connectivity and accessibility through Lockhart City Park (Figures 1-1 and 1-2). The Area of Potential Effects (APE) is 0.98 acres in size (Appendix A: Design Plans). Concrete path construction will cause disturbance of up to one foot below the existing grade along the alignment of the path. As the project will be located on lands under purview of an entity of the State of Texas, the project is subject to compliance with the Antiquities Code of Texas (ACT). During coordination with the Texas Historical Commission (THC) it was determined that the APE located east of State Highway (Hwy) 183 would require survey prior to construction (Appendix B: Regulatory Correspondence).

Archeological survey was conducted on October 8, 2019 by Benjamin Johnson and Steven Sarich and on October 17, 2019 by Pollyanna Clark, Josh Haefner, Benjamin Johnson and Steven Sarich. During the survey, five shovel tests were excavated and four no dig locations were recorded. Due to the proximity of the APE to marked graves, the presence of the broken grave marker deposited downslope, and the inaccuracy of the currently mapped cemetery boundary on the THC Atlas, TRC recommended that the portion of the APE that coincides with the Lockhart Cemetery be subject to machine scraping. On November 5, 2019 the survey area was revisited to conduct mechanical scraping where the APE was noted to be in proximity to marked burials. No evidence of any cultural materials or grave shafts were encountered during monitoring of scraping. 


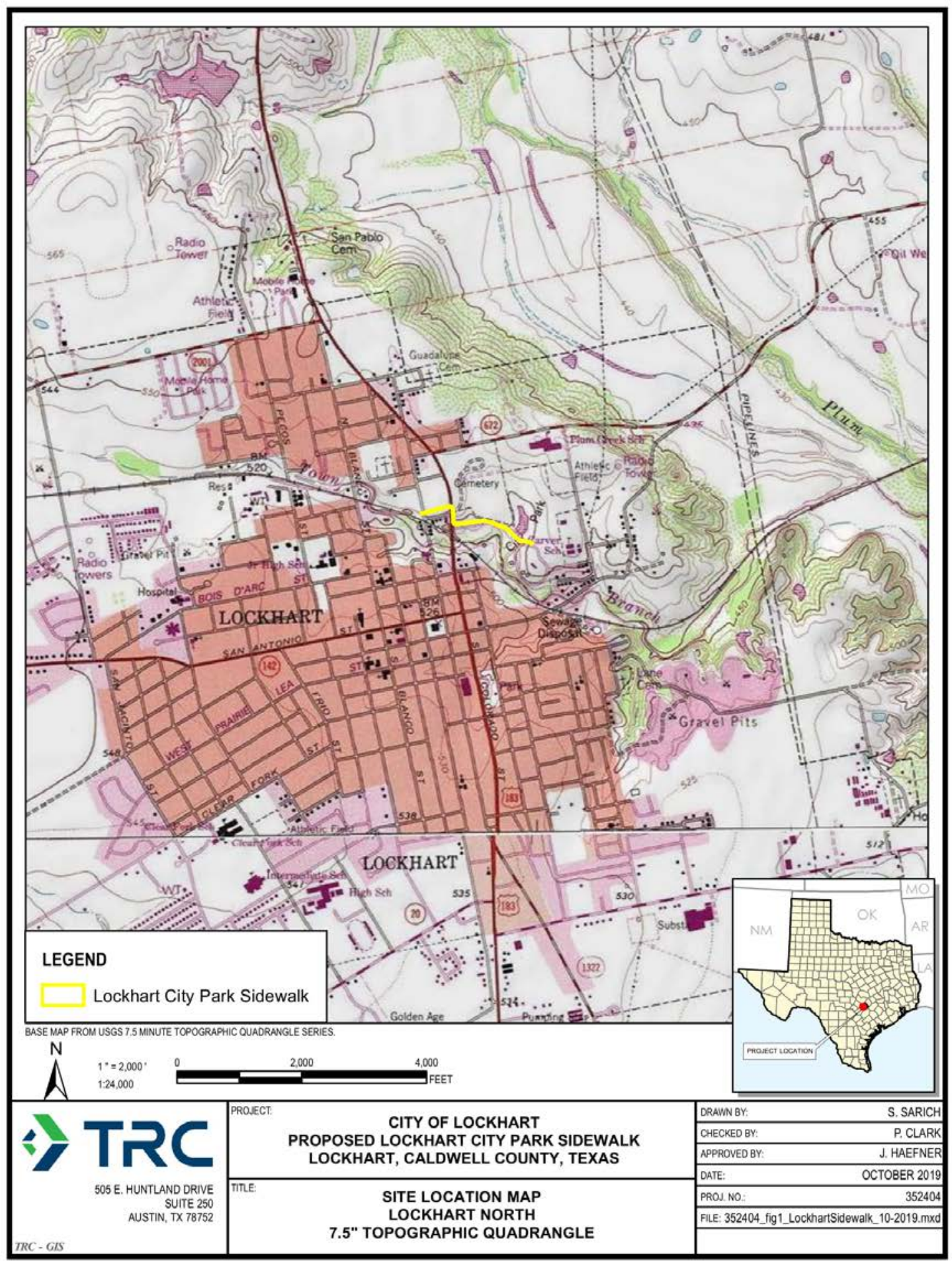

Figure 1-1: $\quad$ Topographic map of APE. 


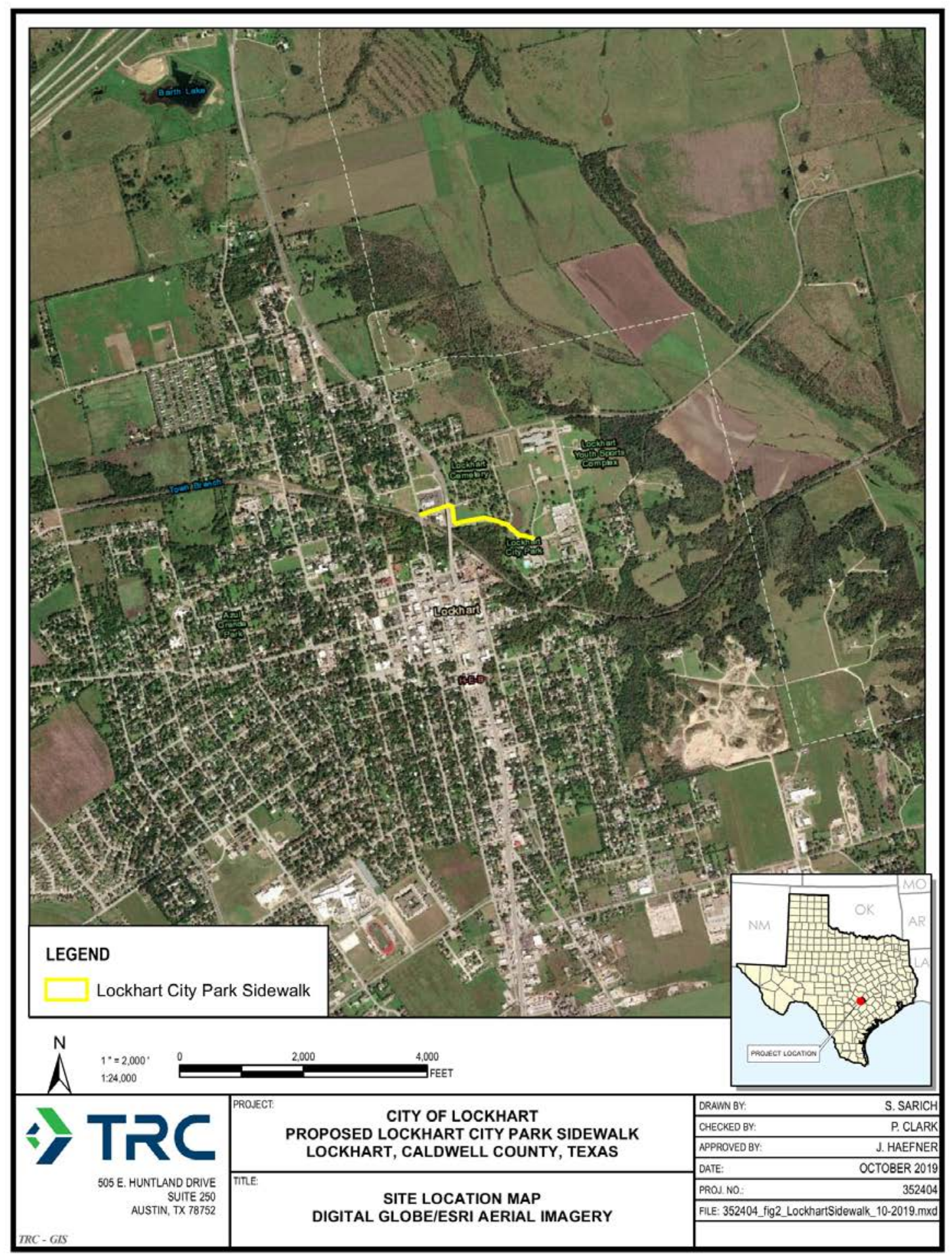

Figure 1-2: $\quad$ Aerial map of APE. 
This page intentionally left blank. 


\subsection{GEOLOGIC AND PEDOLOGIC CONTEXT}

According to the Geologic Atlas of Texas (Seguin Sheet), the geology of the APE is mapped as the Leona Formation (Qle) of Pleistocene age and consists of fluvatile terrace deposits of gravel, sand, silt, and clay on the first wide terrace of the Nueces and Leona Rivers, below the level of the Uvalde Formation (Figure 2-1). The soils within the APE are mapped as Branyon clay (BrB) and Queeny gravelly loam (QuF) according to the USDA Natural Resources Conservation Service Web Soil Survey (Figure 2-2). Branyon clay $(\mathrm{BrB})$ with 1 to 3 percent slopes is characterized by calcareous clayey alluvium derived from mudstone of Pleistocene age originating from stream terraces. A typical profile includes 0 to 203 centimeters $(\mathrm{cm})$ of clay and this series comprises the majority of the APE. Queeny gravelly loam (QuF) with 5 to 20 percent slopes consists of gravelly alluvium of Quaternary age and are derived from mixed sources from paleoterraces. A typical profile includes 0 to $18 \mathrm{~cm}$ of gravelly loam, 18 to $28 \mathrm{~cm}$ of cemented material, and 28 to $183 \mathrm{~cm}$ of variable materials. 


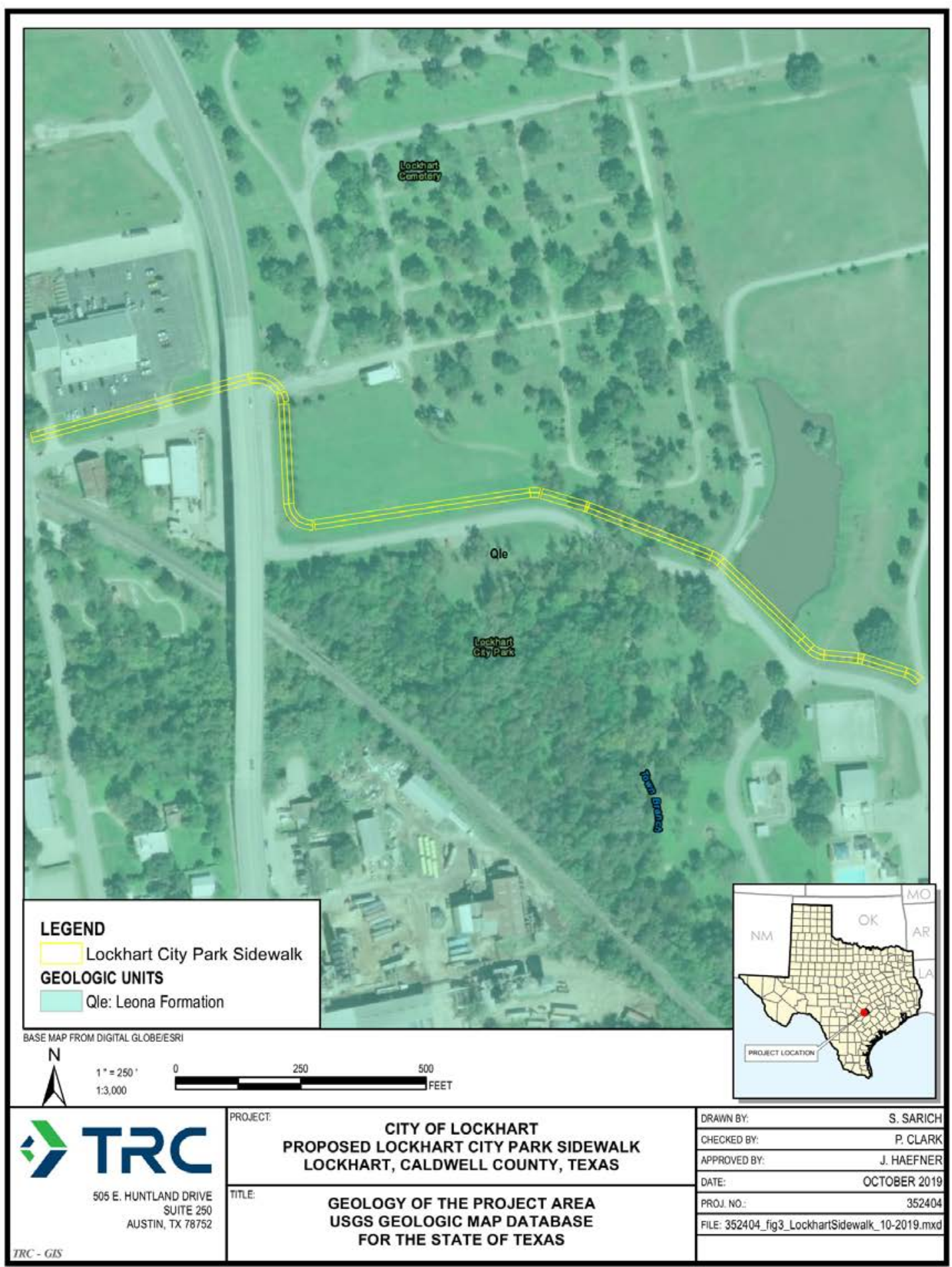

Figure 2-1: $\quad$ Underlying geology within and adjacent to the APE. 


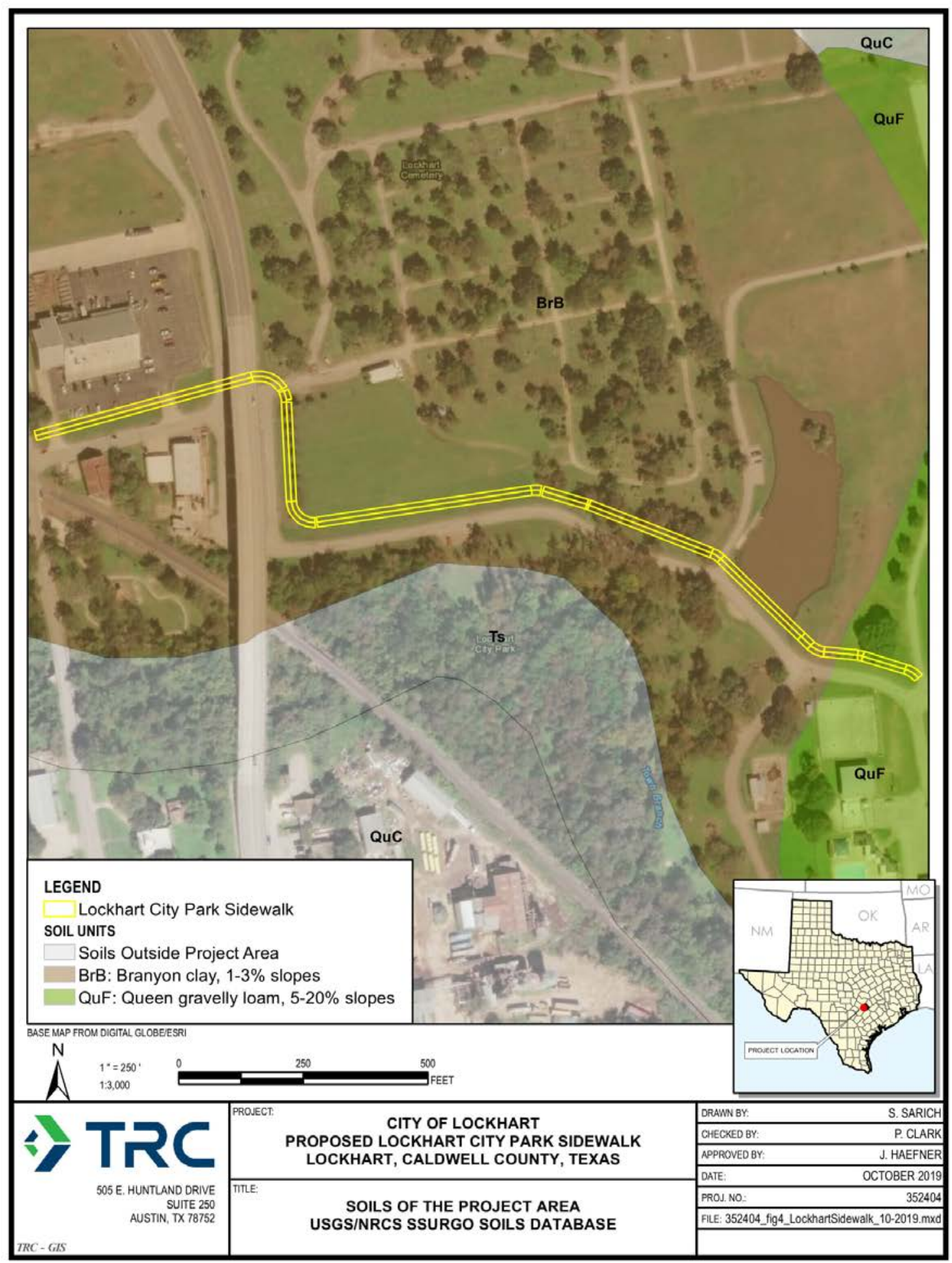

Figure 2-2: Soils within and adjacent to the APE. 
This page intentionally left blank 


\subsection{PREVIOUS INVESTIGATIONS}

Prior to fieldwork, background research was conducted to identify the location and distribution of previously recorded archeological sites and investigations within the vicinity of the APE using the THC's online Archeological and Historic Sites Atlas (THC-Atlas). According to the THC-Atlas, no previously recorded archeological sites, historical markers, State Antiquities Landmarks, or National Register of Historic Places properties are located within or adjacent to the APE (Figure 3-1). One cemetery, City Park (Lockhart Municipal Burial Park) intersects the APE and continues adjacent to the APE on the northern side (THC-Atlas 2019). The cemetery is visible on historic topographic maps from 1911 to the present and includes documented burials as early as 1815. A review of historical topographic maps 1911 (San Marcos 1:125,000), 1919 (San Marcos 1:125,000), and 1963 (Lockhart North 1:24,000) depict a cemetery at this location. Google Earth imagery depicts no change in the cemetery boundary from 1995 to the present. Lockhart Municipal Burial Park is described in Table 3-1. The table also lists four previously recorded archeological sites, two National Register of Historic Places (NRHP) properties, and one NRHP District located within 1 mile of the APE. According to the Atlas, the APE has not been previously surveyed for cultural resources. However, five linear surveys have been conducted within 1 mile of the APE and are listed in Table 3-2. Only one site, 41CW67, was recorded during these surveys (THC-Atlas 2019). Thirteen historical markers are also located within 1 mile of the APE and are listed in Table 3-3 below. 
Figure 3-1: $\quad$ Figure Redacted Due to Sensitive Site Data. 
Table 3-1: $\quad$ Previously Recorded Cultural Resources within a 1 mile of the APE.

\begin{tabular}{|c|c|c|c|}
\hline $\begin{array}{c}\text { Resource Type } \\
\text { and Distance } \\
\text { from APE }\end{array}$ & $\begin{array}{l}\text { Resource } \\
\text { Name }\end{array}$ & Description & Eligibility \\
\hline $\begin{array}{l}\text { Historic and } \\
\text { Prehistoric } \\
\text { Archeological Site, } \\
0.27 \mathrm{mi}(0.44 \mathrm{~km}) \text { west } \\
\text { of APE }\end{array}$ & 41CW19 & $\begin{array}{l}\text { Site 41CW19 was recorded by John W. Clark in } 1979 \text { and is located within } 3 \text { lots of } \\
\text { a city block with early, mid, and late nineteenth century structures. The areas } \\
\text { between and around the site structures exhibit numerous historic and prehistoric } \\
\text { artifacts from early nineteenth through early twentieth century and unknown } \\
\text { prehistoric lithic artifacts. Historic artifacts observed include historic ceramics, cut } \\
\text { nails, bottles, and numerous iron fragments. Prehistoric artifacts observed include } \\
\text { flint flakes, cores, and a biface fragment. }\end{array}$ & $\begin{array}{l}\text { Unassessed by } \\
\text { THC }\end{array}$ \\
\hline $\begin{array}{l}\text { Historic and } \\
\text { Prehistoric } \\
\text { Archeological Site, } \\
0.39 \text { mi }(0.63 \mathrm{~km}) \\
\text { northeast of APE } \\
\end{array}$ & 41CW67 & $\begin{array}{l}\text { Site 41CW67 was recorded in } 2000 \text { by Dan Prikryl from the Lower Colorado River } \\
\text { Authority (LCRA) for the Dumphill to Lockhart Transmission Line Improvements } \\
\text { project. The site consists of late nineteenth to early twentieth century trash and } \\
\text { unknown prehistoric lithic scatters. Materials observed include historic ceramics and } \\
\text { prehistoric debitage and one chert scraper. }\end{array}$ & $\begin{array}{l}\text { Ineligible } \\
\text { within project } \\
\text { right-of-way } \\
\text { by THC } \\
8 / 28 / 2000 \\
\end{array}$ \\
\hline $\begin{array}{l}\text { Prehistoric } \\
\text { Archeological Site, } \\
0.93 \mathrm{mi}(1.5 \mathrm{~km}) \\
\text { northeast of APE }\end{array}$ & 41CW105 & $\begin{array}{l}\text { Site 41CW105 was recorded in } 2007 \text { by Cody Kiker from LCRA for the LCRA T- } \\
125 \text { Maintenance CRA Survey Project. The site is defined as a light scatter of burned } \\
\text { rock, lithic flakes, a quartzite hammerstone, and a moderate scatter of mussel shell } \\
\text { fragments. Site integrity and research potential are unknown according to the site } \\
\text { form due to a combination of } 3 \text { major factors: much of the site has been plowed, } \\
\text { limited testing was conducted, and a dense stand of cane covers a portion of the site. }\end{array}$ & $\begin{array}{c}\text { Undetermined } \\
\text { eligibility by } \\
\text { THC }\end{array}$ \\
\hline $\begin{array}{l}\text { Prehistoric } \\
\text { Archeological Site, } \\
0.60 \mathrm{mi}(0.97 \mathrm{~km}) \\
\text { northeast of APE }\end{array}$ & 41CW106 & $\begin{array}{l}\text { Site 41CW106 was recorded in } 2007 \text { by Cody Kiker from LCRA for the LCRA T- } \\
125 \text { Maintenance CRA Survey Project. The site consists of flakes, mussel shell } \\
\text { fragments, and a Scallorn point spread across the surface of the site with subsurface } \\
\text { deposits including more mussel shell, flakes and flake tools, along with burned rock } \\
\text { and burned flakes. Site } 41 \text { CW } 106 \text { was recommended to have potential for high } \\
\text { research value due to its overall integrity and needs further investigation. }\end{array}$ & $\begin{array}{c}\text { Undetermined } \\
\text { eligibility by } \\
\text { THC }\end{array}$ \\
\hline $\begin{array}{l}\text { Cemetery, intersecting } \\
\text { and adjacent to APE }\end{array}$ & $\begin{array}{l}\text { City } \\
\text { Park/Lockhart } \\
\text { Municipal } \\
\text { Burial Park }\end{array}$ & $\begin{array}{l}\text { The City Park Cemetery, also called Lockhart Municipal Burial Park includes 6,221 } \\
\text { interments from } 1815 \text { to the present. The cemetery intersects and is adjacent to the } \\
\text { northern side of the APE. It is also depicted on historic topographic maps from the } \\
\text { San Marcos, Texas (1911) USGS 1:125,000 Topographic Quadrangle up through the } \\
\text { Lockhart North, Texas (1963, } 1994 \text { ed.) USGS 7.5' Topographic Quadrangle. }\end{array}$ & N/A \\
\hline $\begin{array}{l}\text { Cemetery, } 0.38 \mathrm{mi} \\
(0.61 \mathrm{~km}) \text { north of } \\
\text { APE }\end{array}$ & $\begin{array}{l}\text { Guadalupe } \\
\text { Cemetery }\end{array}$ & $\begin{array}{l}\text { According to www.findagrave.com, the Guadalupe Cemetery includes } 5 \text { interments } \\
\text { from } 1975 \text { to the present. An aerial from Google Earth depicts a significantly larger } \\
\text { amount of burials covering approximately } 4.64 \text { acres. The THC-Atlas does not have } \\
\text { any information on file and an internet search did not provide any additional } \\
\text { information. }\end{array}$ & N/A \\
\hline $\begin{array}{l}\text { Cemetery, } 0.89 \mathrm{mi} \\
(1.43 \mathrm{~km}) \text { northwest of } \\
\text { APE }\end{array}$ & $\begin{array}{l}\text { San Pablo } \\
\text { Cemetery }\end{array}$ & The San Pablo Cemetery includes 64 interments from 1934 to the present. & N/A \\
\hline $\begin{array}{l}\text { Cemetery, } 0.16 \mathrm{mi} \\
(0.26 \mathrm{~km}) \text { northwest of } \\
\text { APE }\end{array}$ & $\begin{array}{l}\text { Cementerio } \\
\text { Navarro } \\
\text { Historico }\end{array}$ & $\begin{array}{l}\text { The Cementerio Navarro Historico cemetery includes } 350 \text { graves dating from } 1901 \text { to } \\
\text { the present. Historical marker placed in } 2005 \text { designating the cemetery as a Historic } \\
\text { Texas Cemetery. }\end{array}$ & N/A \\
\hline $\begin{array}{l}\text { Cemetery, } 0.44 \mathrm{mi} \\
(0.71 \mathrm{~km}) \text { southeast of } \\
\text { APE }\end{array}$ & Lane Cemetery & The Lane Cemetery includes 204 burials from the 1885 to the present. & N/A \\
\hline $\begin{array}{l}\text { NRHP Property } 0.26 \\
\text { mi }(0.42 \mathrm{~km}) \text { southeast } \\
\text { of APE }\end{array}$ & $\begin{array}{l}\text { Lockhart } \\
\text { Vocational } \\
\text { High School }\end{array}$ & $\begin{array}{l}\text { The Lockhart Vocational High School (LVH), also called Carver High School, is } \\
\text { located at } 1104 \text { East Market Street. The two-story stucco building was built in } 1923 \\
\text { and contains six classrooms, a principal's office, and an auditorium. LVH is the last } \\
\text { extant example of two six-teacher type schools constructed in Texas in } 1923 \text { with } \\
\text { funds from the Julius Rosenwald School Building Program. The Rosenwald Fund } \\
\text { was established in } 1917 \text { for the advancement of African American education through } \\
\text { the erection of modern schoolhouses in the rural South. }\end{array}$ & $\begin{array}{l}\text { Listed on the } \\
\text { NRHP in } 1998\end{array}$ \\
\hline $\begin{array}{l}\text { NRHP Property } 0.30 \\
\text { mi }(0.49 \mathrm{~km}) \\
\text { southwest of APE }\end{array}$ & $\begin{array}{l}\text { Emmanuel } \\
\text { Episcopal } \\
\text { Church }\end{array}$ & $\begin{array}{l}\text { The Emmanuel Episcopal Church was built in } 1856 \text { and is presumed to be the oldest } \\
\text { Protestant Church still in use in Texas. The structure is small, one-story, with Gothic } \\
\text { trim, pitched roof, and utilizes the basic plan of an entrance vestibule and central nave. }\end{array}$ & $\begin{array}{l}\text { Listed on the } \\
\text { NRHP in } 1974\end{array}$ \\
\hline $\begin{array}{l}\text { NRHP District } 0.23 \mathrm{mi} \\
(0.37 \mathrm{~km}) \text { south of } \\
\text { APE }\end{array}$ & $\begin{array}{l}\text { Caldwell } \\
\text { County } \\
\text { Courthouse } \\
\text { District }\end{array}$ & $\begin{array}{l}\text { The Caldwell County Courthouse Historic District surrounds the Caldwell County } \\
\text { Courthouse Building which was built in 1893, is three-stories, and is in the Second } \\
\text { Empire architectural style. The surrounding buildings are late nineteenth century } \\
\text { commercial buildings are one of the best examples in Texas of a courthouse square } \\
\text { commercial district. }\end{array}$ & $\begin{array}{l}\text { Listed on the } \\
\text { NRHP in } 1978\end{array}$ \\
\hline
\end{tabular}


Table 3-2: $\quad$ Previously conducted archeological surveys within a 1 mile of the APE.

\begin{tabular}{|l|l|c|}
\hline \multicolumn{1}{|c|}{$\begin{array}{c}\text { Distance and } \\
\text { Direction from } \\
\text { APE }\end{array}$} & \multicolumn{1}{c|}{ Archeological Survey Description } & $\begin{array}{c}\text { Texas Antiquities } \\
\text { Committee Permit No }\end{array}$ \\
\hline $\begin{array}{l}\text { Linear Archeological } \\
\text { Survey, } 0.09 \text { mi }(0.15 \\
\text { km) south of APE }\end{array}$ & $\begin{array}{l}\text { The linear survey was conducted in } 2000 \text { on behalf of the Texas Parks and } \\
\text { Wildlife Department and no sites were recorded during the project. }\end{array}$ & N/A \\
\hline $\begin{array}{l}\text { Linear Archeological } \\
\text { Survey, } 0.45 \text { mi }(0.72 \\
\text { km) south of APE }\end{array}$ & $\begin{array}{l}\text { The linear survey was conducted in } 1998 \text { on behalf of the Texas Water and } \\
\text { Development Board (TWDB) and no sites were recorded during the project. }\end{array}$ & N/A \\
\hline $\begin{array}{l}\text { Linear Archeological } \\
\text { Survey, } 0.42 \text { mi }(0.68 \\
\text { km) southwest of APE }\end{array}$ & $\begin{array}{l}\text { The linear survey was conducted in } 1998 \text { on behalf of the Texas Water and } \\
\text { Development Board (TWDB) and no sites were recorded during the project. }\end{array}$ & N/A \\
\hline $\begin{array}{l}\text { Linear Archeological } \\
\text { Survey, } 0.17 \text { mi }(0.27 \\
\text { km) east of APE }\end{array}$ & $\begin{array}{l}\text { The linear survey was conducted in } 2000 \text { by the LCRA for the Dumphill to } \\
\text { Lockhart Transmission Line Improvements Project during which site 41CW67 } \\
\text { was recorded. }\end{array}$ & Permit \#2308 \\
\hline $\begin{array}{l}\text { Linear Archeological } \\
\text { Survey, } 0.82 \text { mi (1.32 } \\
\text { km) northeast of APE }\end{array}$ & $\begin{array}{l}\text { The linear survey was conducted in } 1992 \text { on behalf of the Federal Highway } \\
\text { Administration and no sites were recorded during the project. }\end{array}$ & N/A \\
\hline
\end{tabular}

Table 3-3: $\quad$ Historical Markers within a 1 mile of the APE.

\begin{tabular}{|c|c|c|c|}
\hline $\begin{array}{c}\text { Resource Type } \\
\text { within a one-mile } \\
\text { radius of APE }\end{array}$ & $\begin{array}{l}\text { Marker } \\
\text { Number }\end{array}$ & Marker Name & NRHP Eligibility \\
\hline Historical Marker & 13479 & Cementerio Navarro Historico & Historic Texas Cemetery \\
\hline Historical Marker & 9764 & The Coopwood House & Not Available (N/A) \\
\hline Historical Marker & 9768 & Emmanuel Episcopal Church & Listed on the NRHP in 1974 \\
\hline Historical Marker & 9776 & Susanna Dickinson Hannig-Messenger of the Alamo & N/A \\
\hline Historical Marker & 9770 & First Christian Church (Disciples of Christ) of Lockhart & N/A \\
\hline Historical Marker & 9759 & Caldwell County Historical Marker & N/A \\
\hline Historical Marker & 9760 & Caldwell County Courthouse & N/A \\
\hline Historical Marker & 9763 & Dr. Eugene Clark Library & N/A \\
\hline Historical Marker & 9761 & Caldwell County Jail & N/A \\
\hline Historical Marker & 9762 & Cardwell Home & N/A \\
\hline Historical Marker & 9783 & Battle of Plum Creek & N/A \\
\hline Historical Marker & 0 & Lockhart Vocational High School (Carver High School) & Listed on the NRHP in 1998 \\
\hline Historical Marker & 9779 & Karback=Flowers Home & N/A \\
\hline
\end{tabular}




\subsection{FIELD METHODS}

The goals of the cultural resources survey were as follows:

- Determine if cultural materials are present within the APE through pedestrian survey and shovel testing of the APE;

- If archeological deposits are present within the APE, determine their spatial extent;

- If archeological deposits are present within the APE, attempt to determine the general cultural affiliation/age of these deposits;

Fieldwork was conducted by TRC archeologists Steven Sarich and Ben Johnson on October 8, 2019 and by Steven Sarich, Ben Johnson, Polly Clark, and Josh Haefner on October 17, 2019 with subsequent monitoring of mechanical scraping for unmarked graves conducted by Polly Clark and Erin Hamilton on November 5, 2019 and followed the guidelines and survey standards set forth by the Council of Texas Archeologists (CTA) and the THC. The APE measures approximately 0.98 acres in size, however after correspondence with THC personnel it was determined that the portion of the APE west of Hwy 183 did not require survey. The portion of the APE subject to investigation measures approximately 0.82 acres in size and it was anticipated that approximately seven tests would be excavated during the investigation if no cultural materials or features were encountered. Additionally, the APE overlaps the southern boundary of the Lockhart Cemetery. This portion of the APE is to be subject to visual inspection to make note of interments within close proximity to the APE and determine the potential for unmarked burials. This data was used to determine if mechanical scraping prior to construction was necessary. Subsequent to the survey, a small portion the APE in close proximity to a cemetery plot at grade with the APE was subjected to mechanical scraping.

Field investigations consisted of survey of the APE supplemented with shovel testing. The APE was traversed in a single linear transect and the ground surface was thoroughly inspected for prehistoric and historic-age cultural resources. TRC excavated a total of five shovel tests and recorded four No Dig shovel tests within the APE. Shovel tests were approximately 30-40-centimeter (cm) (11.8-inch) in diameter, and excavated to at least $100 \mathrm{cmbs}$, when culturally sterile subsoil was encountered, or soils were heavily compacted and/or exhibited heavy disturbance, or at bedrock gravels. Excavated soils were screened through 1/4-inch (6.25-millimeter [mm]) hardware mesh to ensure consistent artifact recovery. Standardized field notes were maintained for each shovel test describing location, soil depth, color, texture, stratigraphy, as well as the types of artifacts recovered. The location and results of all shovel tests were recorded with an electronic form created by TRC with Fulcrum, a mobile form builder and data collection app and connected via Bluetooth to a Trimble sub-meter Global Positioning System unit. The Fulcrum application runs on Android or iOS operating systems and allows users to upload their data in real time (http://www.fulcrumapp.com/). The data can be viewed online allowing the client to monitor the progress of a project as the data is uploaded in the field. In areas absent of standing water, shovel testing was done along a single transect in intervals spaced 50-100 meters apart.

While the majority of the APE was well downslope of the Lockhart City Cemetery, during survey it was noted that a small segment of the APE immediately adjacent to the cemetery was on the same level grade 
with the nearest marked burial located 9.4 meters to the north. Because of this, it was determined that mechanical scraping should be utilized at this location to check for evidence of unmarked graves (Figure 4-1). Monitoring of this effort consisted of mechanically scraping from the northeast corner of the high probability area working westward and southward and excavating in depths of approximately $10 \mathrm{cmbs}$ increments.

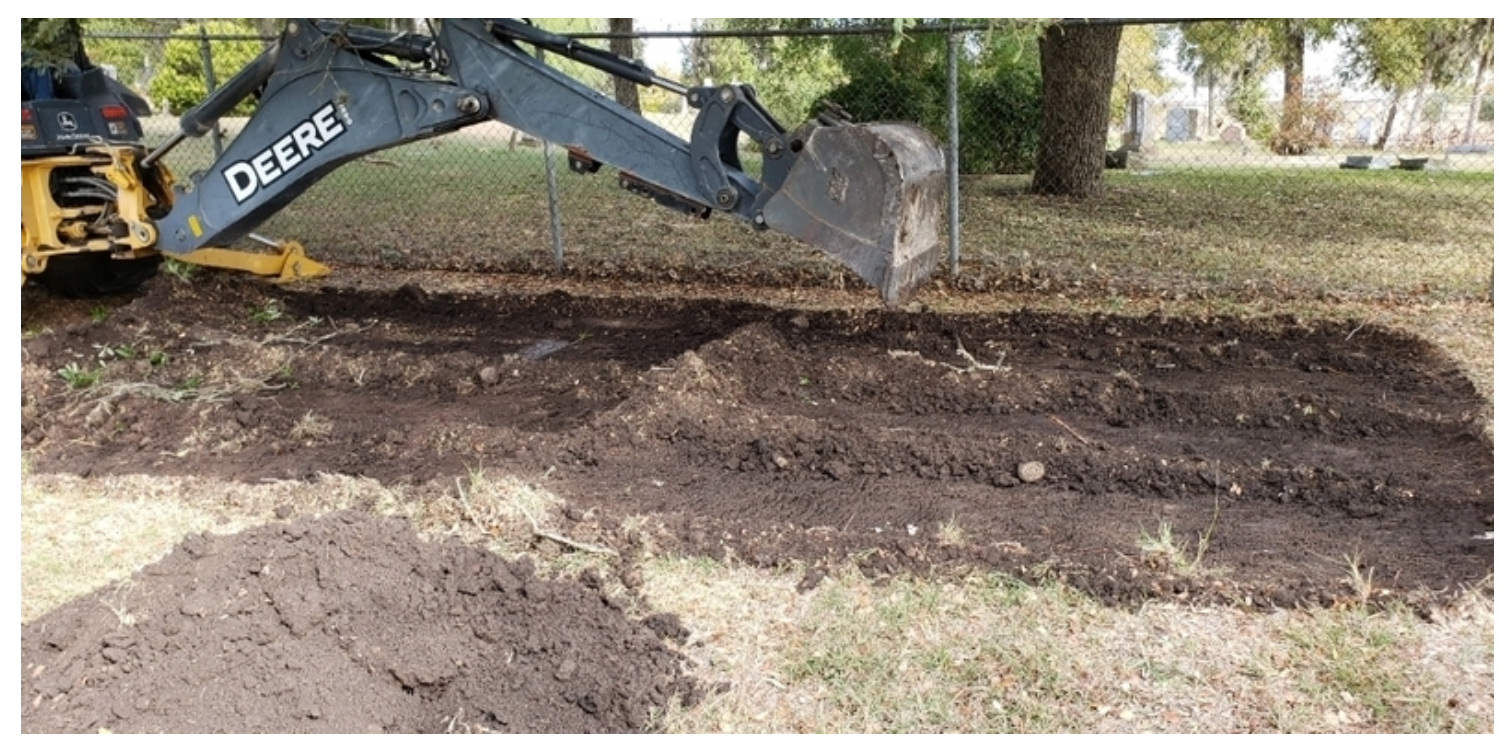

Figure 4-1: Overview of systematic mechanical scraping in progress, facing north.

A "no collection" policy was followed for all cultural materials identified during the survey. No standing structures over 45 years of age were observed within the APE. The final report, field notes, photographs, shapefiles, and associated paper and electronic records will be housed at the TRC office in Austin, Texas. 


\subsection{RESULTS OF SURVEY}

For survey of the APE within Lockhart City Park, archeologists conducted shovel testing along a single linear transect along the proposed centerline of the APE located east of Hwy 183 (Figure 5-1). During the initial survey on October 8, 2019, shovel tests were spaced no more than 100 meters (m) apart. Observed disturbances include underground utilities and landscaping. Shovel test ST-002-SS was excavated near the base of a steep, south facing slope and immediately north of City Park Road (Figure 5-2). Shovel testing noted 7.5YR 3/3 dark brown silty clay loam soils with approximately 5060\% mixed gravel which limited the shovel test depth to $0-10$ cmbs. Similar soils with heavy amounts of gravel were noted for ST-002-BJ and ST-004-SS. Moving east from this location, ST-003-SS was recorded as a No Dig test as it coincided with the portion of the APE that runs along the southern bank of a large pond (Figure 5-3). Additionally, shovel test ST-005-SS located at the eastern extent of the APE exhibited heavy ground disturbances including the presence of a drainage ditch and road construction gravel (Figures 5-4). Subsequent shovel testing (ST-006-SS and ST-007-SS) conducted during the October 17, 2019 revisit of the survey area encountered soils with heavy gravel content similar to that noted in ST-002-SS and were limited to a depth of $0-10 \mathrm{cmbs}$. None of these shovel tests encountered subsurface artifacts.

Subsequent to shovel testing on October 8, 2019, the portion of the APE that coincides with the Lockhart Cemetery was visually inspected for cultural materials. Initial field notes and photographs of the cemetery in relation to the APE were recorded. While a large portion of the APE that overlaps the cemetery boundary is at the base of a steep, south facing slope with the cemetery upslope to the north, it was noted that a 20$25 \mathrm{~m}$ section of the APE at the southeast corner of the cemetery is at grade with and approximately 5-10 m south of several grave markers. On October 17, 2019, the survey location was revisited at which point the fence line along the southern cemetery boundary was delineated along with the row of marked graves closest to the APE. At its closest point to the cemetery, the APE of the proposed sidewalk is approximately $9.4 \mathrm{~m}$ (30.8 feet) from the nearest row of marked graves (Figures 5-5). During the October 17th revisit, additional visual inspection of the heavily sloped area immediately adjacent to and south of the Lockhart Cemetery led to the discovery of cut stone fragments $(N=2)$ and a single broken grave marker $(N=1)$ with the letters 'C. W.' carved onto the surface (Figures 5-6 and 5-7). No additional diagnostic markers are present on the broken grave marker and identifying the individual associated with the marker is not possible. 


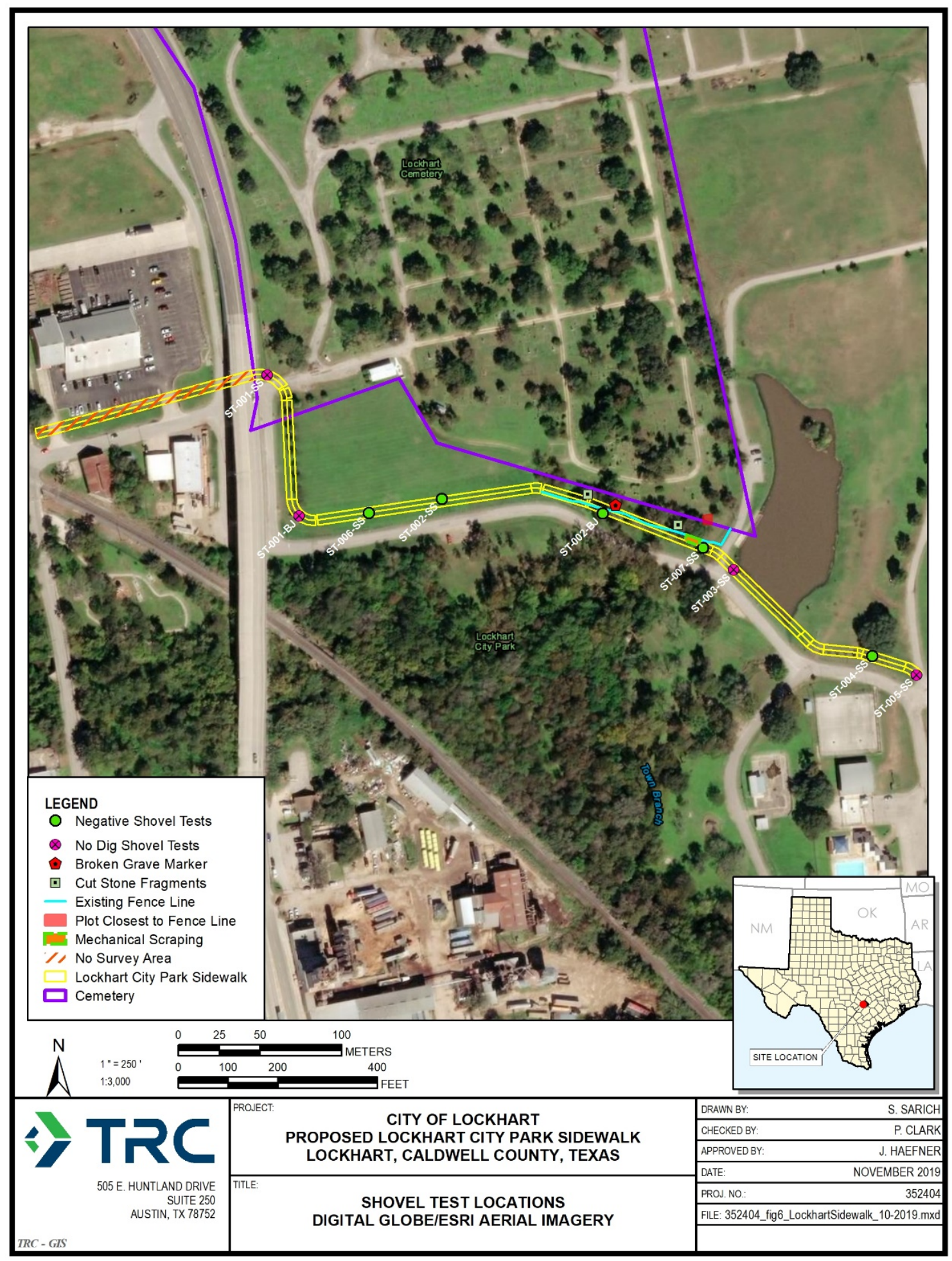

Figure 5-1: $\quad$ Shovel Test and mechanical scraping locations. 


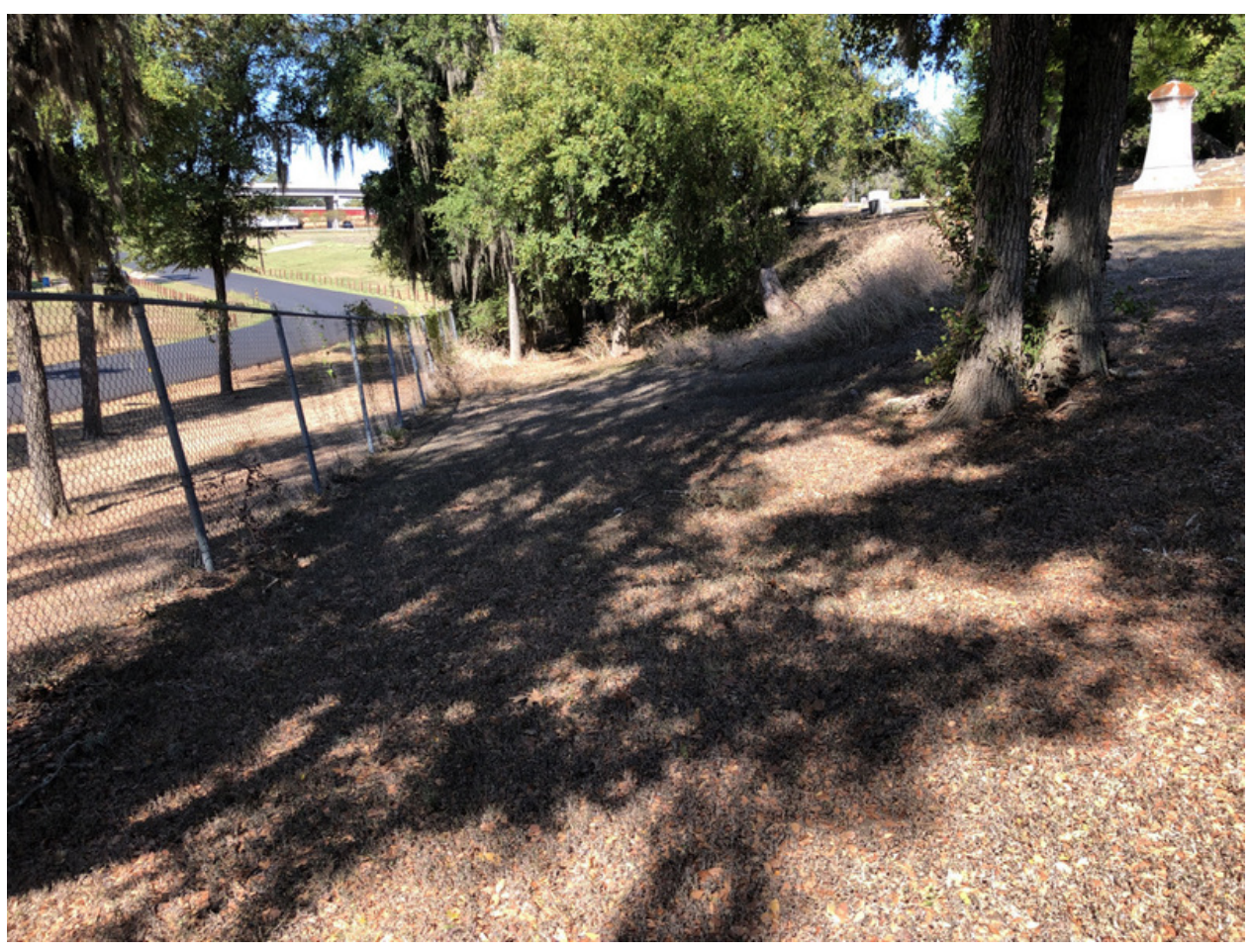

Figure 5-2 Overview of APE, facing west with centerline of 10' wide trail located south of fence line and nearest row of graves upslope to the north.

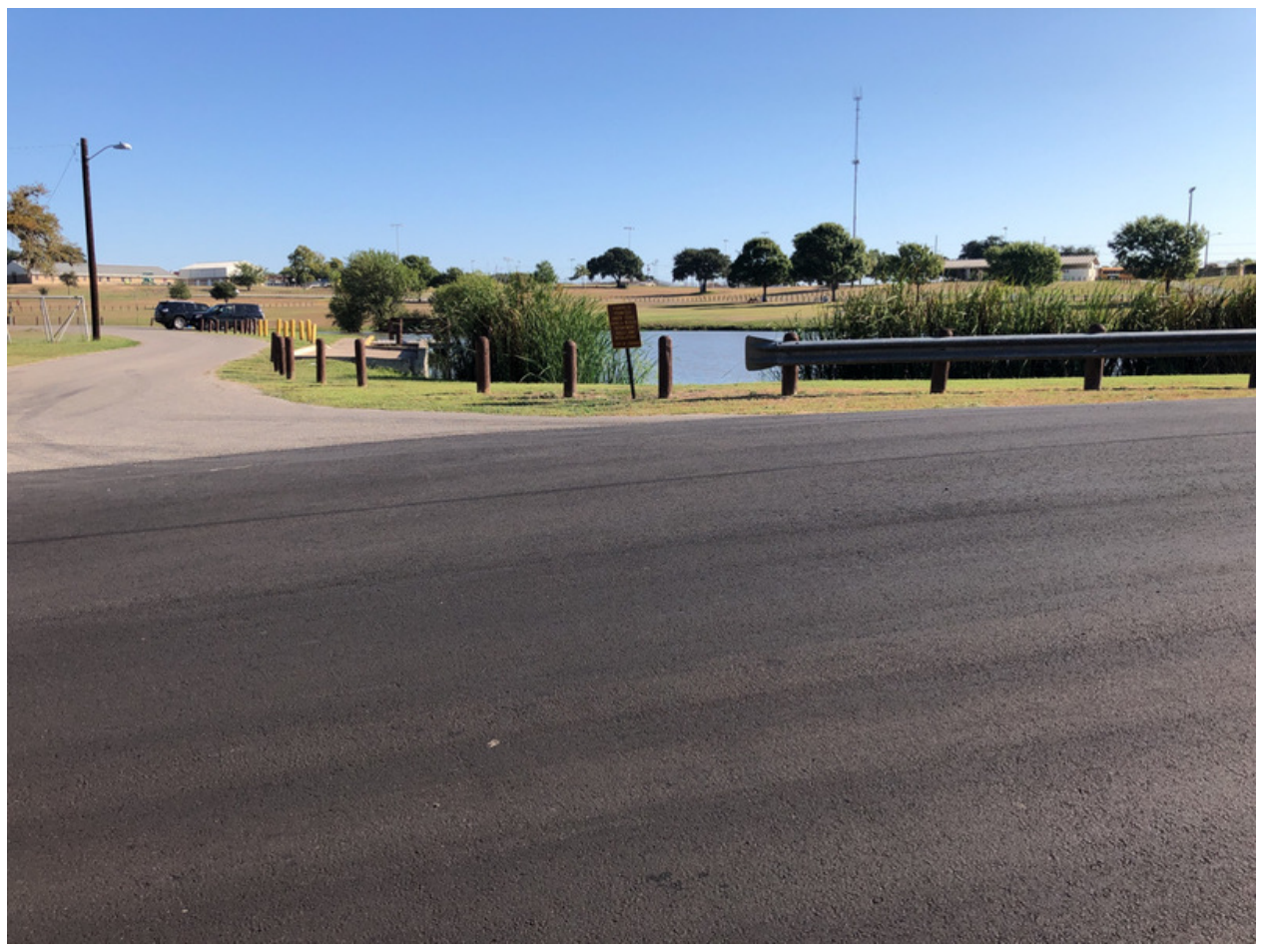

Figure 5-3: $\quad$ Overview of APE, facing northeast showing pond and location of No Dig shovel test ST-003-SS. 


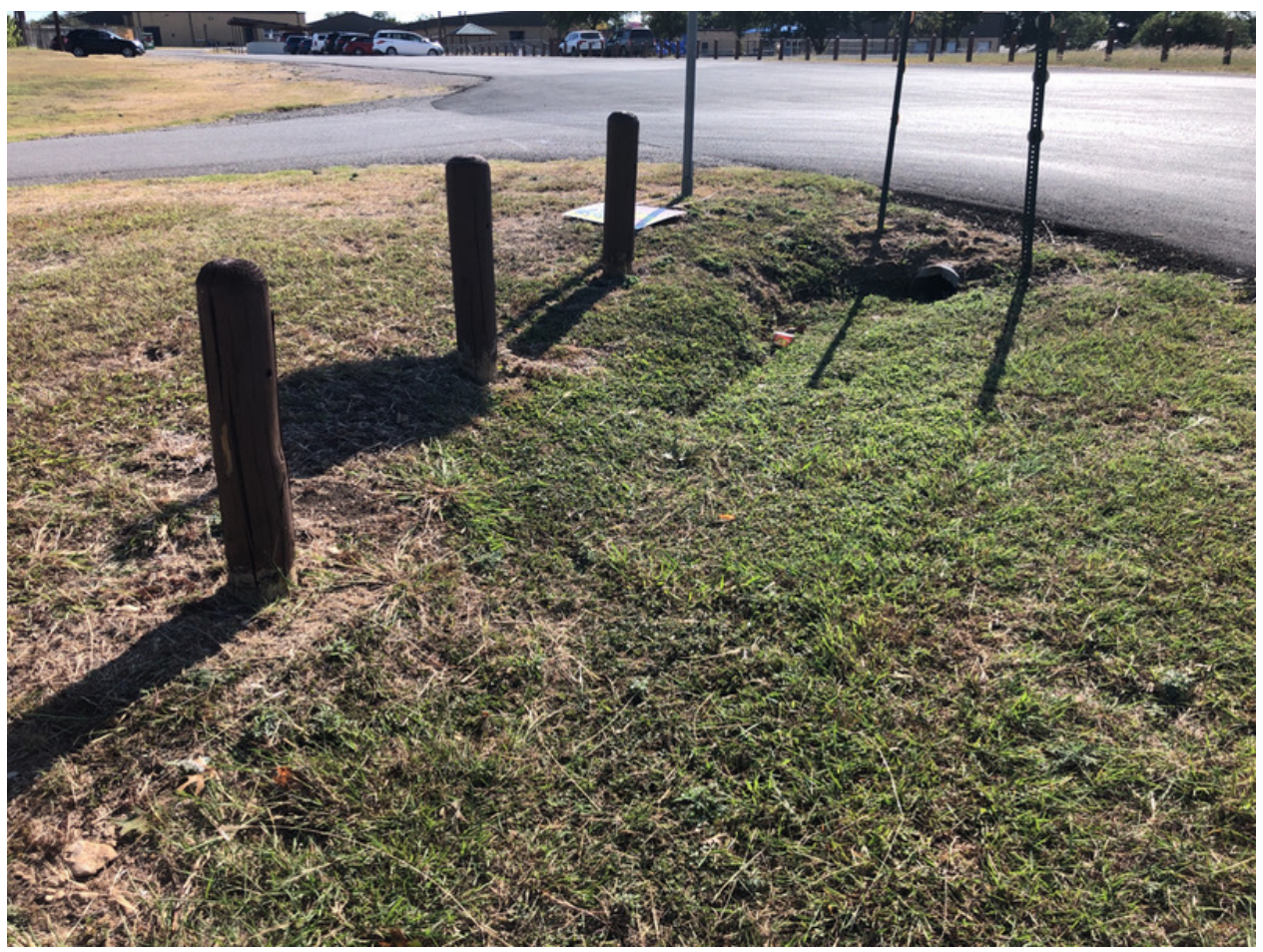

Figure 5-4: Overview of APE, facing east showing the survey end point and ground disturbance.

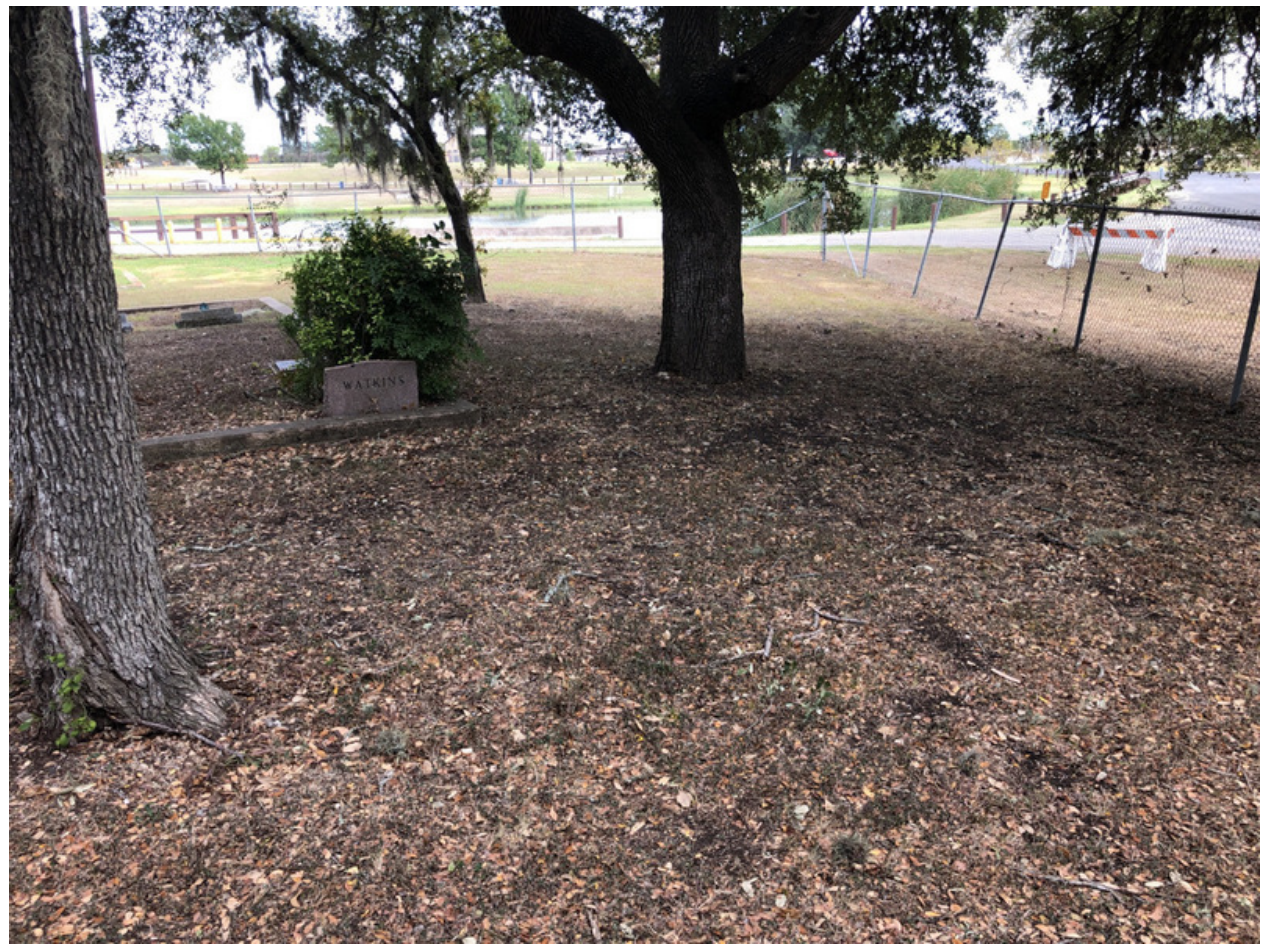

Figure 5-5 Overview of cemetery, facing east; the APE is on the south side of the fence line. 

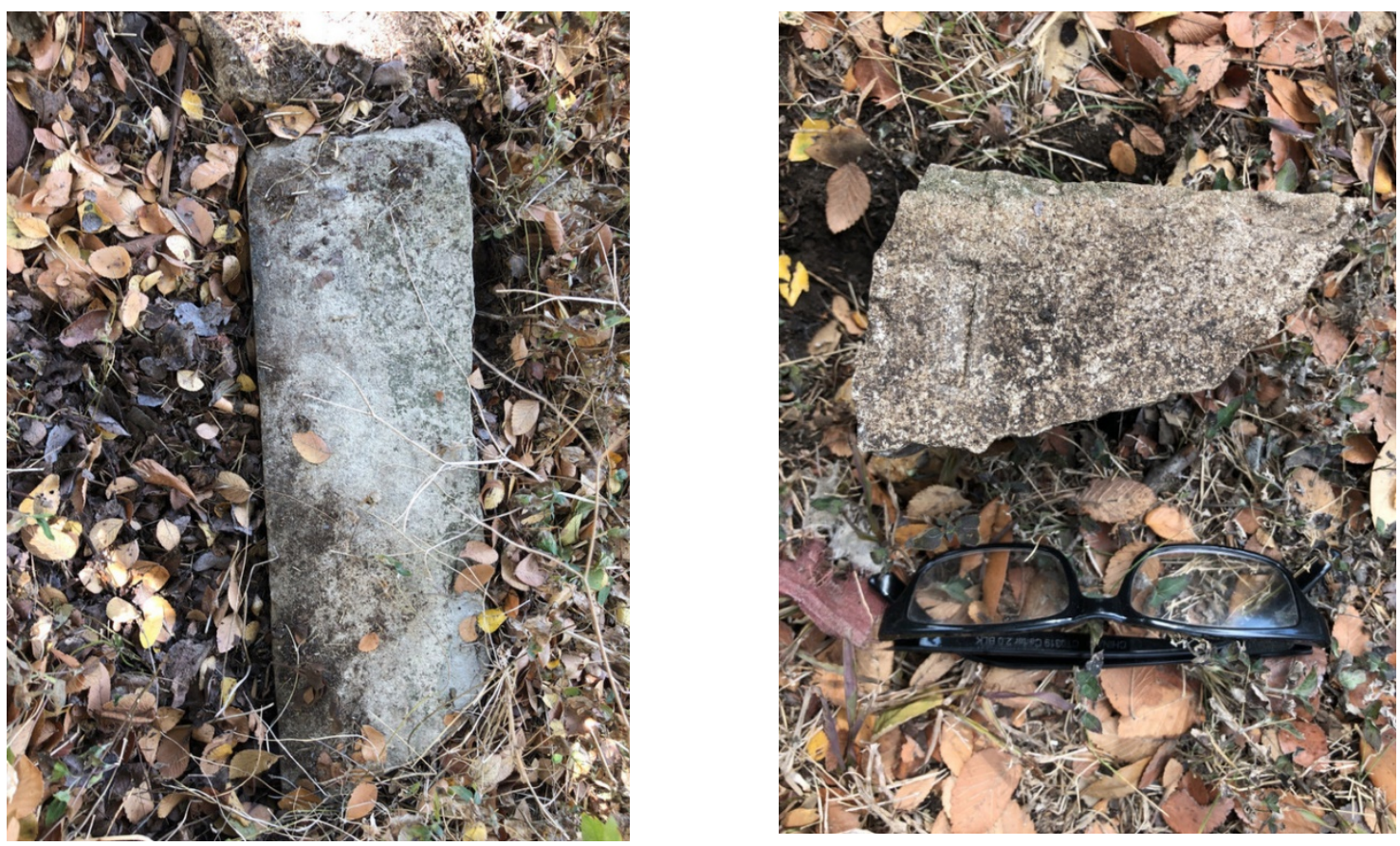

Figure 5-6: $\quad$ Cut stone fragments found downslope from the cemetery along the fence line.

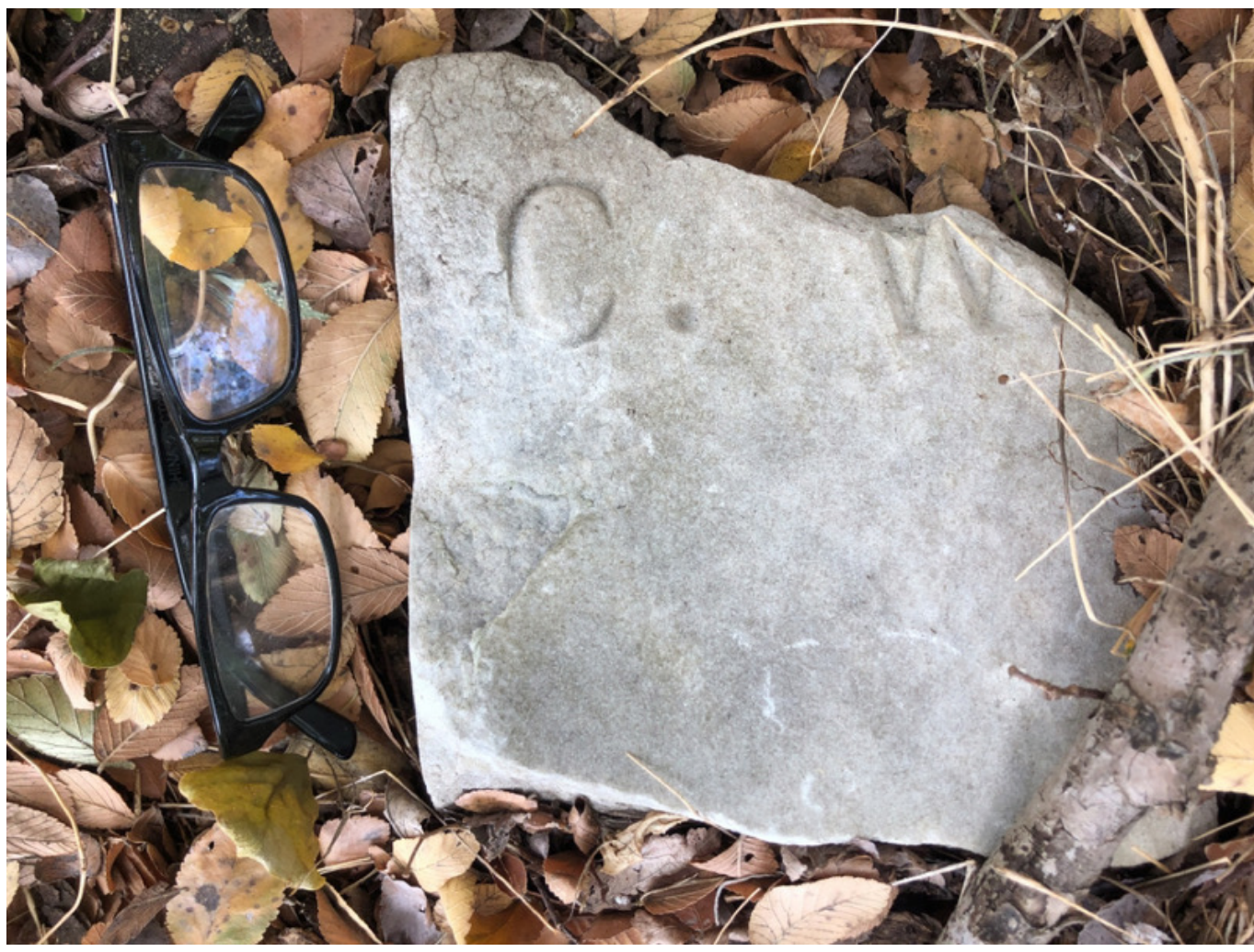

Figure 5-7: $\quad$ Cut stone fragments found downslope from the cemetery along the fence line. 


\section{Mechanical Scraping}

On November 5, 2019, the survey area was revisited to conduct mechanical scraping where the APE was noted to be in close proximity to marked burials on a level landform before downslope to the south and east. The dimensions of the total area scraped were $3.7 \mathrm{~m}$ north to south by $6.5 \mathrm{~m}$ east to west, totaling 24.0 square meters and is located on a hill immediately adjacent to the fence line of the cemetery (Figure 5-8). The western boundary was determined by the significant down sloping of the landform (Figure 5-9). The soil color from 0-65 cmbs is characterized as black clay (Gley $12.5 / \mathrm{N}$ ) and 65-110 cmbs is dark gray clay (Gley $14 / \mathrm{N}$ ) (Figure 5-10). The scraping was terminated consistently throughout the area at approximately $110 \mathrm{cmbs}$ when the backhoe scraped against a dense layer of cobbles (Figure 5-11). No evidence of any cultural materials or grave shafts were encountered during the monitoring of the scraping. 


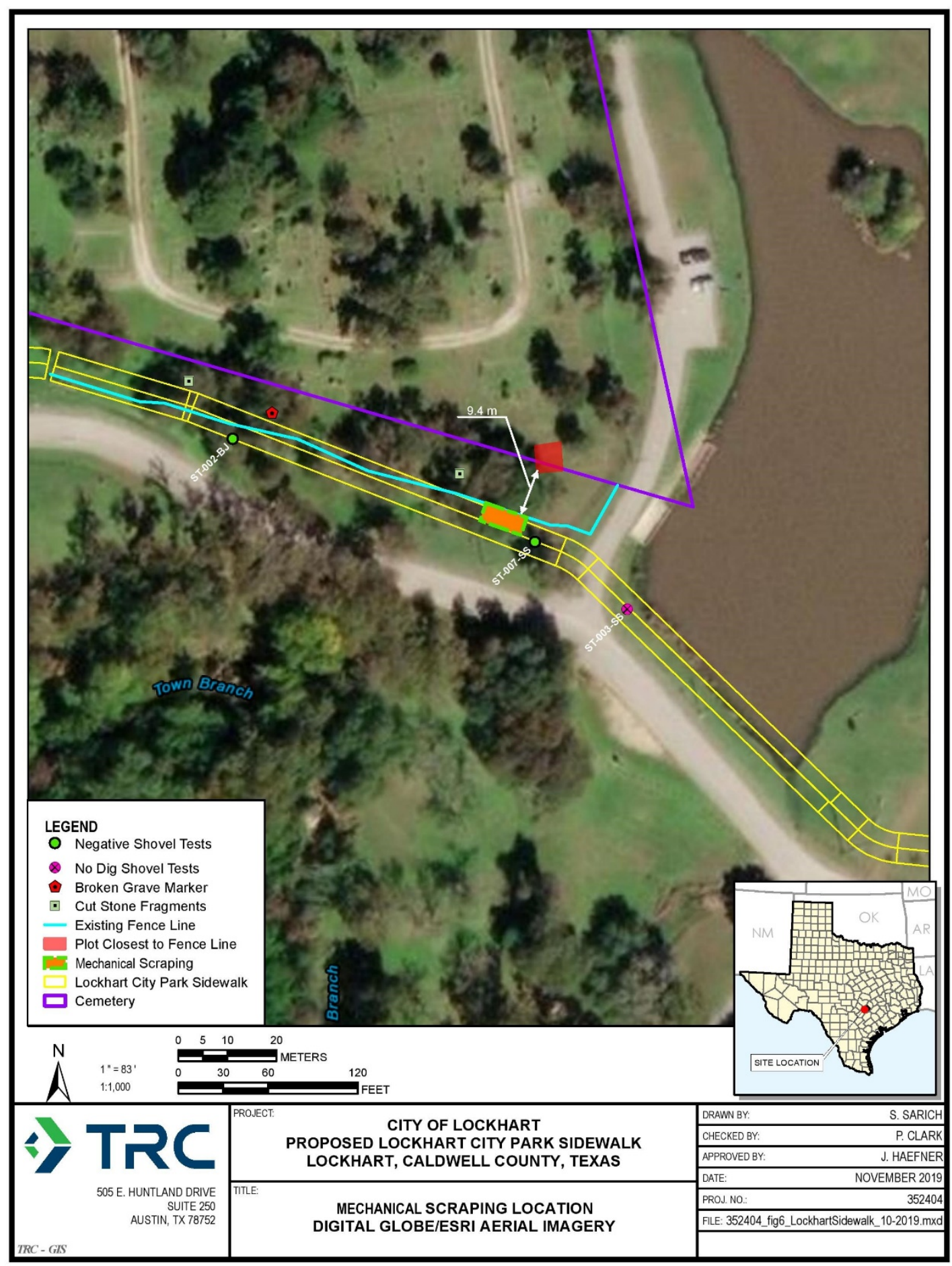

Figure 5-8: Close up of mechanical scraping area in planview. 


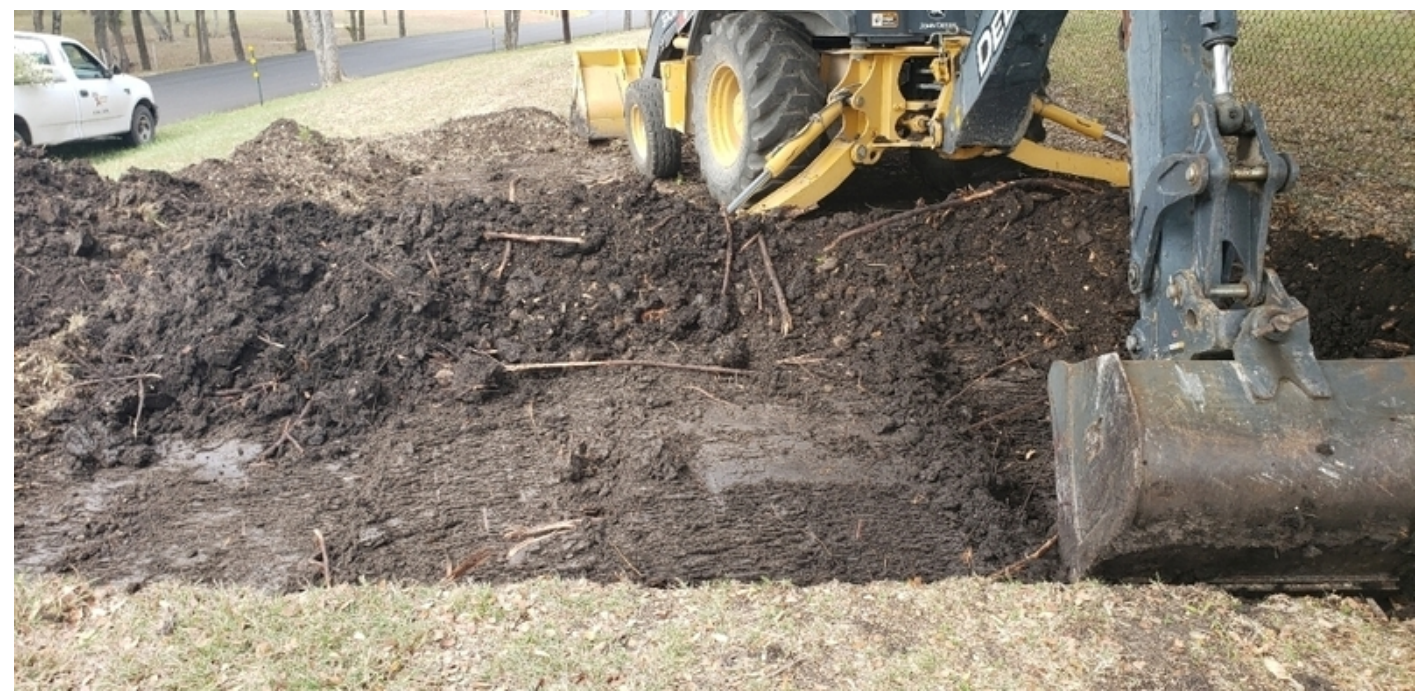

Figure 5-9: Overview of mechanical scraping facing west showing westward sloping landscape.

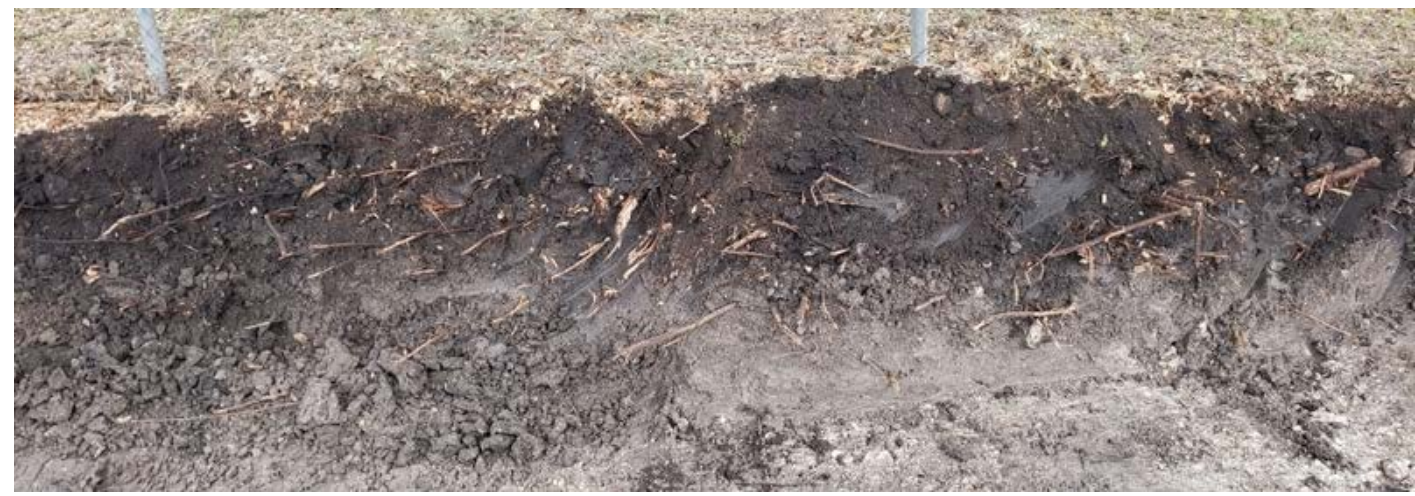

Figure 5-10: Cemetery scraping soil profile facing north.

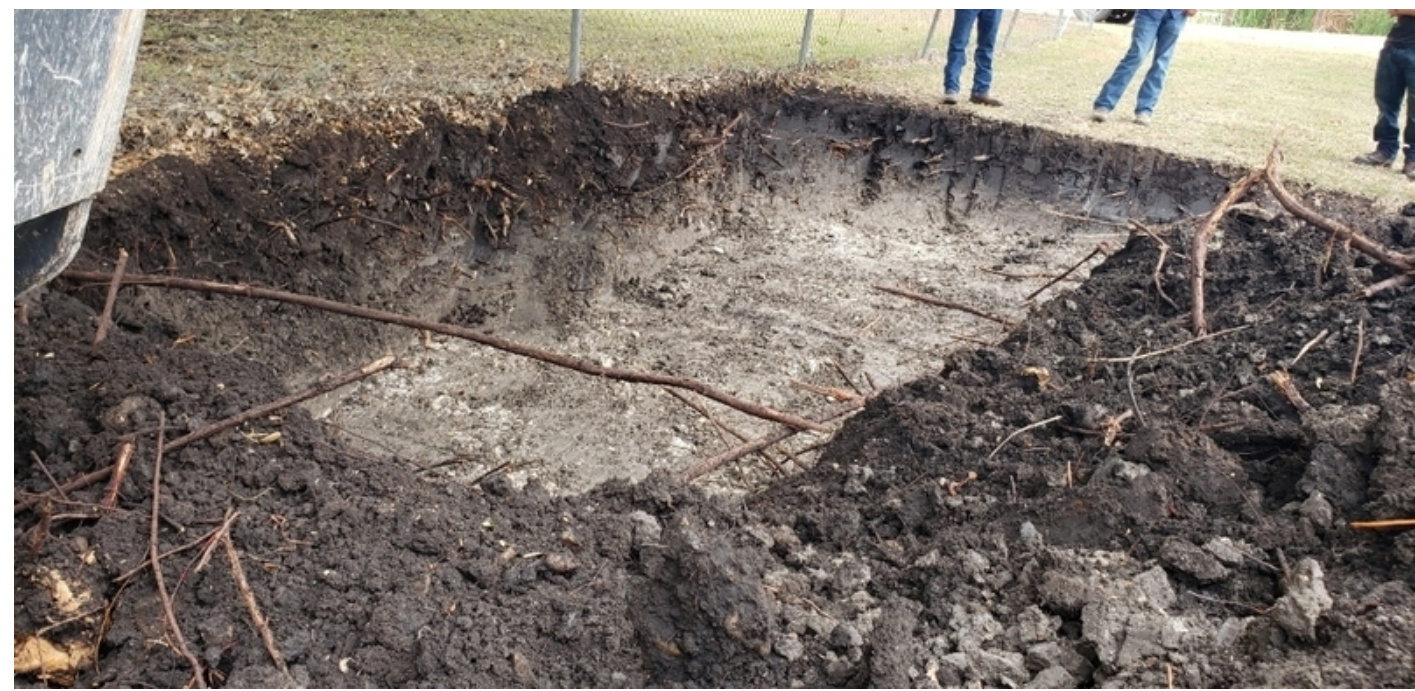

Figure 5-11: Cemetery scraping overview facing northeast terminated at dense layer of cobbles. 


\subsection{PROJECT SUMMARY AND RECOMMENDATIONS}

Fieldwork was conducted on October 8, 2019 and on 17, 2019 under Texas Antiquities Permit \#9126. Investigations consisted of shovel testing and visual inspection of segments of the APE east of Hwy 183 as required by the THC. During the survey, five shovel tests were recorded and four no dig locations. Soils noted in excavated shovel tests consisted of dark brown to black silty clay loam with $50-60 \%$ gravel and were limited to a depth of $0-10 \mathrm{cmbs}$. All shovel tests were negative for cultural materials. Two cut stone fragments and one broken grave marker were noted within or adjacent to the APE. Furthermore, the Lockhart Cemetery is located within and adjacent to a portion of the APE. While this portion of the APE is at the base of a substantial slope with the cemetery at the top of the slope, it was noted that the southeast corner of the cemetery is within close proximity and at grade with and approximately 20-25 m section of

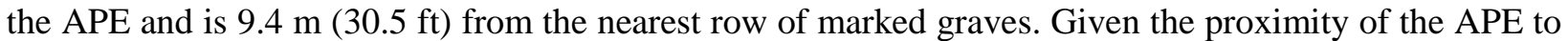
marked graves, the presence of the broken grave marker deposited downslope, and the inaccuracy of the currently mapped cemetery boundary on the THC Atlas, TRC recommended that the portion of the APE that coincides with the Lockhart Cemetery be subject to machine scraping. On November 5, 2019, the survey area was revisited to conduct mechanical scraping where the APE was noted to be in proximity to marked burials. No evidence of any cultural materials or grave shafts were encountered during the monitoring of scraping.

As a result of survey, TRC recommends that the proposed project can proceed to construction. In the event that any human or potential human remains are encountered during construction activities, all work should cease immediately in that specific area and the contractor shall notify local law enforcement, who in turn shall notify the local medical examiner's office. If these remains are not considered recent by the medical officer (i.e., most likely prehistoric in age), then TRC archeologists should be notified and the THC contacted. 
This page intentionally left blank. 


\section{APPENDIX A: DESIGN PLANS}




\section{\& TRC}

505 East Huntland Dr.

Suite 250

Austin, TX 78752
T 512.329.6080

TRCcompanies.com

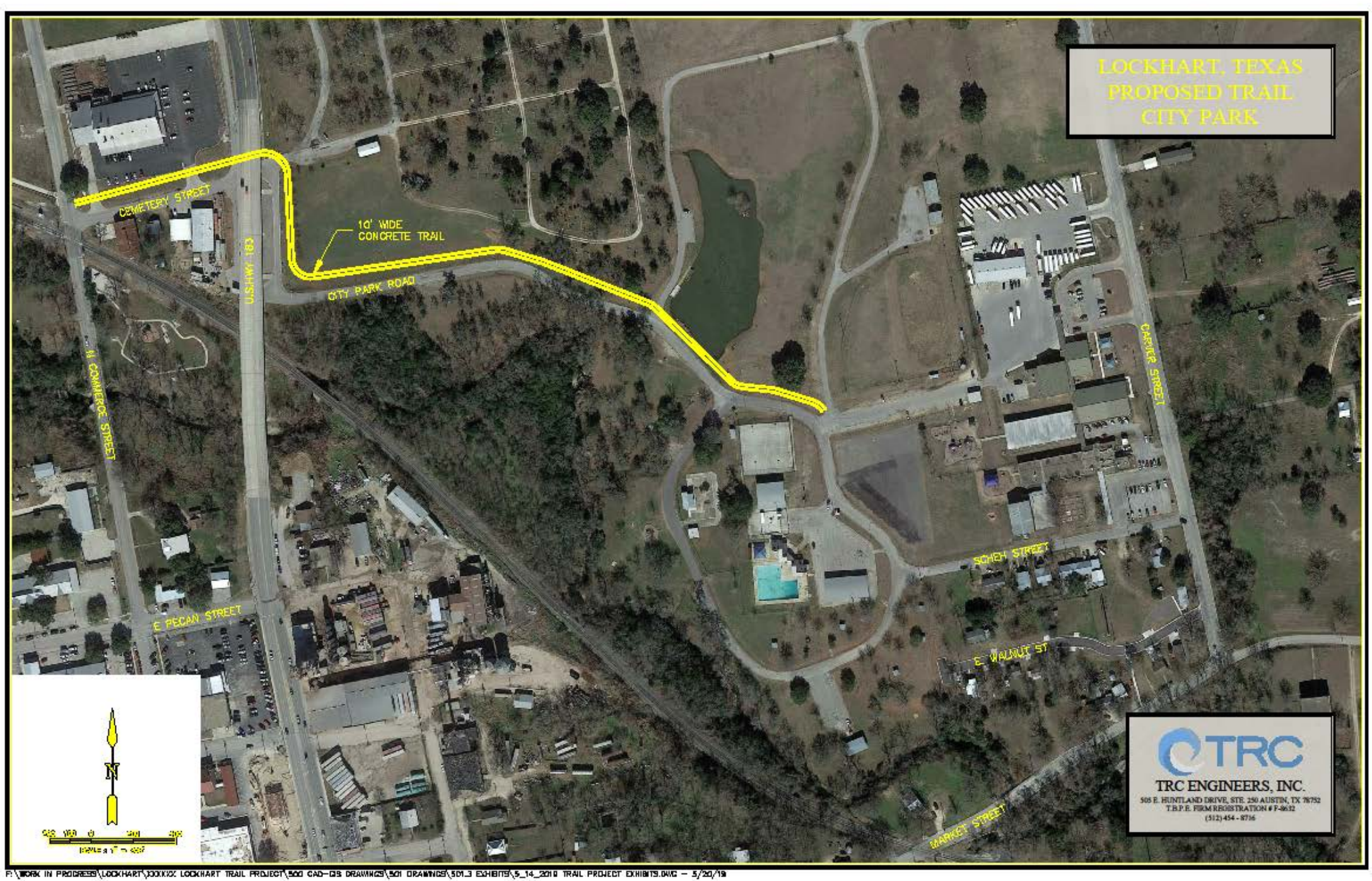




\section{APPENDIX B: REGULATORY CORRESPONDENCE}




$\begin{array}{ll}\text { From: } & \text { noreply@thc.state.tx.us } \\ \text { Sent: } & \text { Monday, September 9, 2019 1:17 PM } \\ \text { To: } & \text { Hamilton, Erin; reviews@thc.state.tx.us } \\ \text { Subject: } & \text { Section 106 Submission }\end{array}$

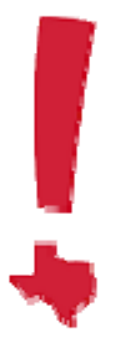

\section{TEXAS HIBTORIGAL COMMIRBION}

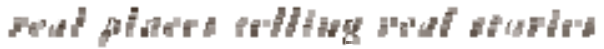

Re: Project Review under Section 106 of the National Historic Preservation Act and/or the Antiquities Code of Texas 201912595

City of Lockhart, Proposed Sidewalk Installation Project-352404Cemetery Street and City Park Road Lockhart,TX 78644

Dear Erin Hamilton:

Thank you for your submittal regarding the above-referenced project. This response represents the comments of the State Historic Preservation Officer, the Executive Director of the Texas Historical Commission (THC), pursuant to review under Section 106 of the National Historic Preservation Act and the Antiquities Code of Texas.

The review staff, led by Jeff Durst and Caitlin Brashear, has completed its review and has made the following determinations based on the information submitted for review:

\section{Above-Ground Resources}

- No historic properties are present or affected by the project as proposed. However, if historic properties are discovered or unanticipated effects on historic properties are found, work should cease in the immediate area; work can continue where no historic properties are present. Please contact the THC's History Programs Division at 512-463-5853 to consult on further actions that may be necessary to protect historic properties.

\section{Archeology Comments}

- An archeological survey is required. The work should meet the minimum archeological survey standards posted online at www.thc.texas.gov. A report of investigations should be produced in conformance with the Secretary of the Interior's Guidelines for Archaeology and Historic Preservation, and submitted to this office for review. In addition, any buildings 45 years old or older that are located on or adjacent to the tract should be documented with photographs and included in the report. If this work will occur on land owned by a state agency or political subdivision of the state, an Antiquities permit must be obtained from this office prior to initiation of fieldwork.

We have the following comments: The portion of the survey area located to the east of HWY 183 needs to be surveyed/ shovel tested.

We look forward to further consultation with your office and hope to maintain a partnership that will foster effective historic preservation. Thank you for your cooperation in this review process, and for your efforts to preserve the 
irreplaceable heritage of Texas. If the project changes, or if new historic properties are found, please contact the review staff. If you have any questions concerning our review or if we can be of further assistance, please email the following reviewers: Jeff.Durst@thc.texas.gov, caitlin.brashear@thc.texas.gov.

Sincerely,

Caithin Brashear

for Mark Wolfe, State Historic Preservation Officer

Executive Director, Texas Historical Commission

Please do not respond to this email. 


\section{TEXAS HISTORICAL COMMISSION \\ real places telling real stories}

Monday, October 21, 2019

Josh Haefner

TRC Companies, Inc.

505 East Huntland Drive, Suite 250

Austin, TX 78752

Re: $\quad$ Project review under the Antiquities Code of Texas

Final Report: City of Lockhart, Proposed Sidewalk Installation Project

Texas Antiquities Permit \# 9126

\section{Dear Colleague:}

Thank you for your Antiquities Permit Application for the above referenced project. This letter presents the final copy of the permit from the Executive Director of the Texas Historical Commission (THC), the state agency responsible for administering the Antiquities Code of Texas.

Please keep this copy for your records. The Antiquities Permit investigations requires the production and submittal of one printed copy of the final report, a completed abstract form submitted via our online system, two copies of the tagged PDF final report on CD (one with site location information \& one without), and verification that any artifacts recovered and records produced during the investigations are curated at the repository listed in the permit. The abstract form maybe submitted via the THC website (www.thc.state.tx.us) or use url:

http://xapps.thc.state.tx.us/Abstract/login.aspx

Additionally, you must send the THC shapefiles showing the boundaries of the project area and the areas actually surveyed via email to archeological_projects@thc.texas.gov.

If you have any questions concerning this permit or if we can be of further assistance, please contact the reviewer, Jeff Durst at (512) 463-8884.

Sincerely,

Nick Barrett:

Antiquities Permit Coordinator

(512) 463-1858

Enclosures

Cc :City of Lockhart 


\section{State of Texas \\ TEXAS ANTIQUITIES COMMITTEE}

ARCHEOLOGY PERMIT 9126

This permit is issued by the Texas Historical Commission, hereafter referred to as the Commission, represented herein by and through its duly authorized and empowered representatives. The

Commission, under authority of the Texas Natural Resources Code, Title 9, Chapter 191, and subject to the conditions hereinafter set forth, grants this permit for:

\section{Intensive Survey}

To be performed on a potential or designated landmark or other public land known as:

Title: $\quad$ City of Lockhart, Proposed Sidewalk Installation Project

County: Caldwell

Location: East of Hwy 183, begines at intersection of Cemetery St., City of Lockhart TX

Owned or Controlled by: (hereafter known as the Permittee):

City of Lockhart

PO Box 239

Lockhart TX 78644

Sponsored by (hereafter known as the Sponsor

City of Lockhart

PO Box 239

Lockhart TX 78644

The Principal Investigator/Investigation Firm representing the Owner or Sponsor is:

Josh Haefner

TRC Companies, Inc.

505 East Huntland Drive, Suite 250

Austin, TX 78752

This permit is to be in effect for a period of:

5 Years and 0 Months

and Will Expire on:

10/04/2024

During the preservation, analysis, and preparation of a final report or until further notice by the

Commission, artifacts, field notes, and other data gathered during the investigation will be kept temporarily at:

TRC Companies, Inc.

Upon completion of the final permit report, the same artifacts, field notes, and other data will be placed in a permanent curatorial repository at:

\section{Center for Archaeological Studies}

Scope of Work under this permit shall consist of:

An intensive pedestrian archaeological survey with shovel testing of high probability areas that meets or exceeds the State Archeological Survey Standards for Texas. This includes, subsurface shovel testing of pedestrian survey transects and mechanical testing in appropriate alluvial areas, see attached scope for more detail. 
This permit is granted on the following terms and conditions:

information will be recovered and preserved and must include the scientific, techniqustoric, scientific, archeological, and educational commonly used in archeological investigations. All survey level investigations must follow the state survey standards andion and analysis 2) The Principal Investis with the projects sponsor(s).

specimens, samples, artifacts, materials and records that are collected as a result of this peroject Sponsor, is responsible for insuring that original field notes, maps, will be accomplished at no charge to the Commission, and all permit are appropriately cleaned, and cataloged political subdivision, and must bs, and photographs resulting from the investigations remain the propects, materials, samples, and copies of any requested records shall be fumishtified repository. Verification of curation by the repository of the State of Texas, or its 3) The Principal Investigator/lnverige fumished to the Commission before any permit will be considered is also required, and duplicate publication of results of thinvestigation Firm serving for the Owner/Permittee, and/or the Project Sponsor complete. photographs. A draft copy of the rations in a thorough technical report containing relevant descriptions, maps, docusible for the requested by the Commission must must be submitted to the Commission for review and approval. draft has been approved by the Commise or addressed in the report, or under separate written respon changes to the draft report location of any and all sites recorded ansion, one (1) printed, unbound copy of the final report containing at to the Commission. Once a to the commission. One copy must includ two copies of the report in tagged PDF format on an archival quality CDe map with the plotted location data. A paper copy and an electronic plotted location of any and all sites recorded and the quality CD or DVD shall be fumished submitted with the final report to the Commic copy of the completed Abstracts in Texas Contract Archeology Sumbt include the site www.thc. state.tx.us.) www.thc. State.tx. us.)
4) If the Owner/Permittee, Project Sponsor or Principal Investigator/Investigation Firm fails to the Commission or also online at time, the permit will fall into with any of the specific terms of this permit, or fails to properly conducty with any of the Commission's Rules of the Principal Investigator will not be eligible to botication of Default status shall be sent to the Principal Investe this project within the allotted applicable, extended.

ith until such time that the conditions of this permit are complete or, if must comply with all laws, ordinances and regulations of the State of Texas and of its, political subdivisions including, hereby authorizes,
Antiquities Code of Texas; the or easement holders or other persons conduct the investigation in such a manner as to afford protection to including, but not limited to, the possible, to leave it in a state which will not create hazard to property and they must retum the property to its original any and all lessees forces. 6) Any duly authorized and empowered representive of the field records, materials, and specimens being recovered.
7) For reasons of site security associated with historical

Owner, and Investigation Firm shall not issue any press releases, or Project Sponsor (if not the Owner/Permittee), Principal Investigator, regarding the specific location of, or other information that might endanger those resources, or their as directly or indirectly, information has been discovered. 8) This permit may not be assigned by the Principat owns or controls the land where the resource to any other individual, organization, or corporation not specifically mentioned in this permit wermittee, or Project Sponsor in whole, or in part 9) Hold Harmless: The Owner/Permittee hereby expressly releases the State and arees that Out the written consent of the Commission. indemnify, and defend (including reasonable attomey's fees and cost of litigation) the State, its officer/Permittee will hold harmless, nature arising out of, or in any way com every liability, loss, or claim for damages to persons or propert, agents, and employees in their solely for the benefit of the State and the Texas Historith of the activities covered under this permit. The provisions of this por whatsoever otherwise, to any other person or entity. Texas Historical Commission and are not intended to create or grant any rights, paragraph are 10) Addendum: The Owner/Permittee, Project Sponor and attached.

Upon a finding that it is in the best interest of the State, this permit is issued on 10/04/2019.
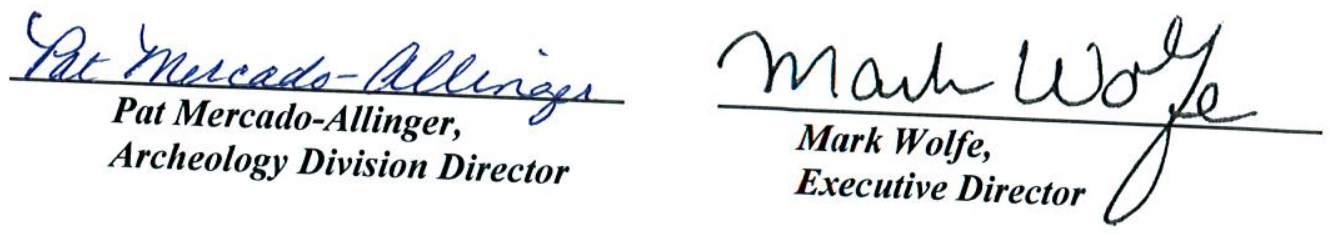